\title{
The orchids of Torres del Paine Biosphere Reserve: The need for species monitoring and ecotourism planning for biodiversity conservation
}

\section{Las orquídeas de la Reserva de la Biosfera Torres del Paine: La necesidad de implementar monitoreo de especies y planificación ecoturística para la conservación de la biodiversidad}

\author{
Osvaldo J. Vidal ${ }^{1}$, Cristina San Martín ${ }^{2}$, Sofía Mardones ${ }^{3}$, Viviana Bauk ${ }^{3}$ \& Claudio F. Vidal ${ }^{4}$ \\ ${ }^{1}$ Albert Ludwigs University, Faculty of Forest and Environmental Sciences, Institute of Silviculture, Tennenbacherstrasse 4, \\ D-79106, Freiburg, Germany. \\ ${ }^{2}$ Universidad Austral de Chile, Facultad de Ciencias, Instituto de Ciencias Ambientales y Evolutivas, Isla Teja, Casilla 567, \\ Valdivia, Chile. \\ ${ }^{3}$ Asociación Medio Ambiental Torres del Paine, Esmeralda 661, Puerto Natales, Chile. \\ ${ }^{4}$ Fantástico Sur Birding and Nature Tours, Armando Sanhueza 579, Punta Arenas, Chile. \\ osvaldo.vidal@me.com
}

\begin{abstract}
The orchid flora of Torres del Paine Biosphere Reserve (TPBR) is described based on botanical surveys, photographical records and herbarium collections carried out by the authors. This list comprises 3 genera and 9 species: Chloraea chica, Chloraea leptopetala, Chloraea magellanica, Codonorchis lessonii, Gavilea araucana, Gavilea gladysiae, Gavilea littoralis, Gavilea lutea and Gavilea supralabellata. G. gladysiae is a new record for this protected area and the first albino aberrant phenotype for flowers of Chl. magellanica is reported. A description of the species including key for determination, morphology, habitats, local abundances, flowering phenology and photographs is provided. The species richness here reported represents ca. $35 \%$ of orchids occurring in the Chilean temperate-austral floristic regions and $75 \%$ of the species described for the Magallanes Region, putting the Torres del Paine Biosphere Reserve as one of the most representative protected areas for this taxonomical group in the region. Based on our results we addressed the need of establishing monitoring programs for orchids and promote them as flagship species in ecotourism planning in order to enhance species valuation and encourage biodiversity conservation.
\end{abstract}

KeYwords: Chloraea, Codonorchis, Gavilea, protected areas, Patagonian flora, flagship species.

\section{RESUMEN}

Se describen las orquídeas de la Reserva de la Biosfera Torres del Paine sobre la base de exploraciones botánicas, registros fotográficos y colecciones de herbario llevadas a cabo por los autores. Esta lista comprende 3 géneros y 9 especies: Chloraea chica, Chloraea leptopetala, Chloraea magellanica, Codonorchis lessonii, Gavilea araucana, Gavilea gladysiae, Gavilea littoralis, Gavilea lutea y Gavilea supralabellata. G. gladysiae es un registro nuevo para esta área protegida y se reporta el primer fenotipo aberrante de flores albinas de Chl. magellanica. Se provee de una descripción de las especies que incluye morfología, habitats, abundancias locales, fenología de floración y fotografías. La riqueza de especies aquí reportada representa cerca del 35\% de las orquídeas que se distribuyen en las regiones florísticas Templada-Austral y el 75\% de las especies descritas para la Región de Magallanes, colocando a la Reserva de la Biosfera Torres del Paine como una de las áreas protegidas más representativas para este grupo taxonómico en Chile. Basados en nuestros resultados recalcamos la necesidad de establecer programas de monitoreo para las orquídeas y promoverlas como especies emblemáticas en planificación ecoturística para así incrementar la valoración de las especies y reforzar la conservación de la biodiversidad.

Palabras clave: Chloraea, Codonorchis, Gavilea, áreas protegidas, flora patagónica, especies emblemáticas. 


\section{INTRODUCTION}

Biodiversity conservation has become a major challenge for managers in protected areas in Chile in the last years. Many of the protected areas show a massive increase in tourist visitation, which is intensifying the disturbance pressure on native terrestrial landscapes, ecosystems and species (Pauchard \& Villarroel 2002, Navarro-Cerrillo et al. 2008). Disturbances derived from touristic activities like soil trampling, road extension or accidental fires are causing detrimental changes on native habitats that occasionally reduce the abundances of native species, promotes biological invasions or alter successional pathways of native ecosystems (Dollenz \& Ivanovic 1996, Vidal 2005, Domínguez et al. 2006, Vidal \& Reif 2011). Consequently, not only the pristine biodiversity is irreversibly deteriorated, but also the quality of the recreational experience in the natural area depauperate.

Torres del Paine Biosphere Reserve is one of the most famous protected areas in Chile, because of the beautiful scenery, the ecosystem representativeness and the heterogeneity of its landscapes (Pisano 1974). This park has taken its name from the impressive granite mountain massif located at the center of the area which characterizes the entire park, but also a remarkable biodiversity can be observed. Landscape diversity includes glaciers, lakes, rivers, Andean desert (Pisano 1974). Ecosystems are also diverse including perennial and deciduous undisturbed oldforests, xerophyte and mesophytes shrublands, Patagonian steppe, Magellanic Tundra and also varied aquatic vegetation communities (Pisano 1974, Armesto et al. 1992, Clausen et al. 2006, Navarro-Cerrillo et al. 2008, Vidal \& Reif 2011). Vascular plants are estimated over 450 species (Vidal 2007), and the fauna includes many mammals like guanacos, foxes, Patagonian huemul, wild cats and the mythic puma (Garay \& Guineo 2003). More than 130 bird species inhabit the park (Couve \& Vidal 2007). Moreover it includes the highest raptor species richness reported in Chile (Jaksic et al. 2002). Thus, all these features have placed Torres del Paine National Park as one of the most reputed Chilean natural areas at an international level, achieving the UNESCO's Biosphere Reserve nomination in 1978. At present almost 150,000 tourists visit the area yearly and the visitors flow between 1990 and 2010 increased by more than $600 \%$ (CONAF, unpublished data).

Although the increase in visits at the area has evident economic benefits for the local people and given international renown to the area, the impact of activities derived from tourism on biodiversity has been occasionally catastrophic. For example, during the last 30 years the national forest service (CONAF) has reported 44 human-caused fires occurred in the protected area, which have affected around 47,000 ha, or ca. $19 \%$ of the park surface (CONAF, unpublished data). The last two fire events occurred in 2005 and 2011-12 and affected 32,000 ha in the park. It destroyed valuable habitats like deciduous forests (Navarro-Cerrillo et al. 2008, Vidal \& Reif 2011) and shrublands dominated by Junellia tridens (Lag.) Moldenke, a southern-Patagonian endemic shrub. Thus, a vertiginous increase of ecotourism that hasn't gone hand in hand with planning and nature conservation, and from a biological point of view, long-term conservation goals seem to be hard to achieve (Pauchard \& Villarroel 2002).

Despite high biodiversity in Torres del Paine at this southern latitude ( $52^{\circ}$ latitudes), a few taxonomical groups have received enough attention for scientific research. Among them, mammals like guanacos, pumas and foxes in the area have been relatively well studied (Ortega \& Franklin 1988, Johnson \& Franklin 1994, Franklin et al. 1999), as well as some birds like raptors (Sarno et al. 2000, Jaksic et al. 2002) and aquatic birds (Garay et al. 1991). Studies on habitats and ecosystems meanwhile, are scarce (Armesto et al. 1992, Clausen et al. 2006, Vidal \& Reif 2011) and other groups like vascular plants have been recorded just throughout surveys inside the Biosphere Reserve (Arroyo et al. 1992, Domínguez et al. 2006). However, no particular taxonomic plant groups have been investigated from an ecological perspective. Especially the orchids represent a very interesting group for taxonomists and ecologists, and have a great potential for ecotourism and conservation (Piluek \& Triboun 2008, Cameron 2010). So far orchids have received little attention in the local and national scientific literature (Lehnebach \& Riveros 2003, Novoa et al. 2006). They have been partially mentioned for the Torres del Paine in preliminary checklists and field guides (e.g. Domínguez 2004, 2006, Vidal 2007), but until now, no one has compiled the available information in a comprehensive scientific paper. This lack of knowledge evidently reduces the potential of the orchids for ecotourism valuation and species conservation. In this work we present the first comprehensive description for the orchids in Torres del Paine. Our objectives include (1) to describe the orchid flora of the Torres del Paine Biosphere Reserve and 2) to propose some measures to increase the related conservation efforts.

\section{MATERIALS AND METHODS}

STUDY AREA

This study was conducted in Torres del Paine Biosphere Reserve, a 242,000 ha area which is located in the administrative province of Ultima Esperanza in the southwest of Chilean Patagonia. This protected area is dominated by both the Paine massif and the Grey glacier, which print to the area a great climatic and landscape heterogeneity (Pisano 1974). The mountain massif consist of Cretaceous sedimentarious rocks intruded by a Mioceneaged laccolith (Altenberger et al. 2003), reaching abruptly 
up to 3,050 m.a.s.l. (Paine Grande), while the Grey glacier represents the south end of the Southern Patagonian Ice Field, the second largest extra polar extent of ice. Climatologically the area belongs to the humid-supratemperate belt (Amigo \& Ramírez 1998) of the Temperat-Austral floristic transition (Bannister et al. 2012), with average temperatures of $10.8^{\circ} \mathrm{C}$ in austral summer (January) and $2^{\circ} \mathrm{C}$ in the winter season (July). Although climate data are available from just one meteorological station located at the park administration (CONAF 2007), a drastic environmental gradient in northwest-southeast direction can be distinguished from the colder and humid areas near the Grey glacier to the warmer and dryer areas Sarmiento Lake. Precipitation was estimated to vary from $1,400 \mathrm{~mm}$ to $350 \mathrm{~mm}$ per year and a concomitantly gradual change in vegetation cover can be observed from perennial Nothofagus betuloides forests to Patagonian steppe.

Field SURVEY AND TAXONOMICAL DETERMINATIONS

The field survey was carried out in different plant communities belonging to each of the biotic provinces defined by Pisano (1974). We surveyed orchids at each flowering season since 2003 until 2010 in all the terrestrial plant communities along the climatic gradient including the ecotone between perennial and deciduous forests, deciduous forests like the "Lenga" forests (Violo-Nothofagion pumilionis), "Nire" forests (Agropyron-Nothofagion antarcticae), mesophytic shrublands like "Chaura" shrublands (EmbothrioPernettyetum mucronatae), xerophytic shrublands like "Neneo" shrublands (Stipo-Mulinetum spinosi), "Murta" shrublands (Empetro-Oreopoletum) and the "Mata Negra" shrublands (Berberido-Junieletum tridentis), xeric steppe like "Coirón" steppe (Festucetum gracillimae), humid steppes like "vega" steppes (Geranio-Festucetum gracillimae), high-Andean vegetation like the "Turba" tundra (Donatienton fascicularis), and also anthropic vegetation like prairies (Poo-trifolietum repentis), road borders and burned forests (Pisano 1974, Roig et al. 1985, Clausen et al. 2006, Vidal \& Reif 2011). As the survey was not spatially and temporarily systematically designed, a measure of commonness was used to describe the degree of orchid population abundance using three criteria: "common" when $>10$ populations has been seen during our survey; "rare" when between 5 to 9 populations has been seen on survey; and "very rare" when $<4$ populations has been seen on survey. Plant collections were made on voucher specimens, and determinations were made using field guides (e.g. Novoa et al. 2006, Guerrido \& Fernández 2007, Vidal 2007) and confirmed by means of taxonomical literature (e.g. Correa 1956, Moore 1983, Chemisquy 2009). In addition, photographic records were made and flowering phenology data were recorded in the field. Voucher specimens were deposited at the herbarium of the Universidad Austral in Valdivia (VALD). Nomenclature follows Lehnebach (2003) and the "International Plant Names Index Project" (Croft et al. 1999).

\section{RESULTS}

We found nine orchid species in the survey carried out in the study area. The list of species elaborated includes: Chloraea chica Kraenzl. \& Speg., Chloraea leptopetala M.N. Correa, Chloraea magellanica Hook.f., Codonorchis lessonii (Brongn.) Lindl., Gavilea araucana (Phil.) M.N.Correa, Gavilea gladysiae Chemisquy, Gavilea littoralis (Phil.) M.N.Correa, Gavilea lutea (Pers.) M.N.Correa and Gavilea supralabellata M.N. Correa. These species can be determined by using the following taxonomical key:

1. Leaves verticillate at the half of the stem, flowers terminal, solitary.

Codonorchis lessonii

1 '. Leaves arranged spirally on the stems, flowers in a raceme producing more than 1 flower.

2. Labellum conspicously 3-lobed.

3. Flowers white.....

Gavilea araucana

3'. Flowers yellow.

4. Median lobe of labellum covered by yellow or orange papillae.

4'. Median lobe of labellum covered by green papillae.

2'. Labellum entire or obscurely 3-lobed.

5. Flowers yellow.

6. Labellum with dense and prominent stipitate papillae.

6'. Labellum with few warts over the veins. Gavilea lutea

5'. Flowers white or greenish.

7. Perianth-segments with linear green veins

7'. Perianth-segments with reticulate green veins.

8. Raceme lax, producing not more than 7 flowers.

8 '. Raceme dense, producing more than 20 flowers. 
In what follows, a morphological description for each species is given, including ecological aspects related to habitat and commonness and phenology:

\section{Chloraea chica Kraenzl. \& Speg.}

Terrestrial herb with stems $20-50 \mathrm{~cm}$, erect. Basal leaves 6-15 x 2-3 cm in a pseudo-rosette, oblong-lanceolate, acute and tapering to wide. Cauline leaves narrower, sheatering the scape. Inflorescence in a lax raceme containing 5-20 bracteate flowers. Bract 7-9 x 2-4 mm, linear-lanceolate, acute, decreasing upwards. Flowers white or cream. Upper outer perianth-segment 8-10 × 3-5 mm, oblong, cucculate and acuminate at apex. Lateral outer perianth-segments lanceolate, acuminate, white with 3-4 longitudinal green veins. Upper inner perianth-segments 7-8 x 3-4 mm, oblong, obtuse, papillose on veins in basal half. Labellum 7-8 x 4$5 \mathrm{~mm}$, entire to obscurely 3-lobed, obtuse, with irregularly lacerate margins, covered by yellow or greenish papillae. Column $7 \mathrm{~mm}$. Capsule ovoid-oblong (Fig. 1a).
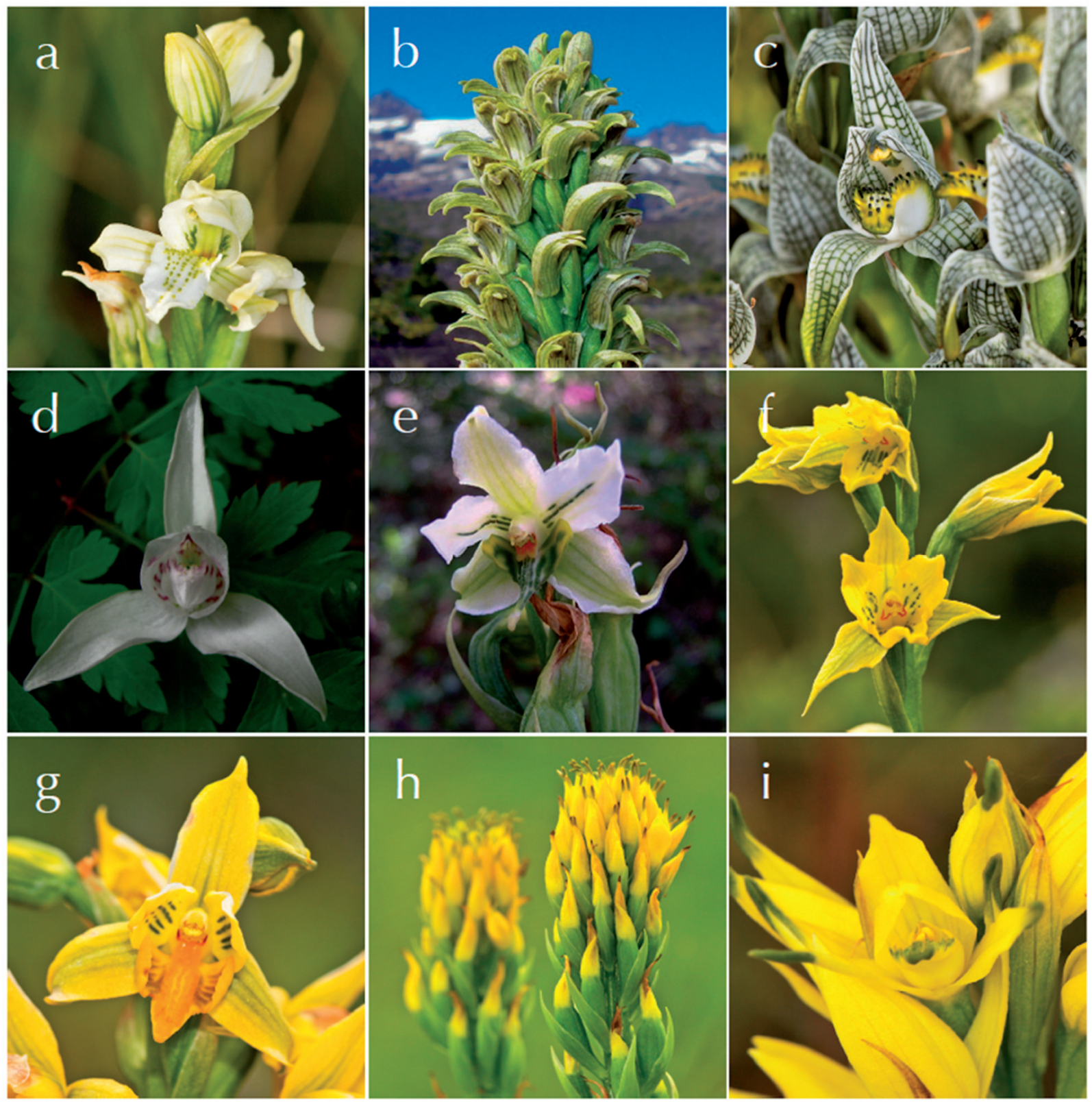

Figure 1. Orchids of the Torres del Paine Biosphere Reserve: a) Chloraea chica; b) Chloraea leptopetala; c) Chloraea magellanica; d) Codonorchis lessonii; e) Gavilea araucana; f) Gavilea gladysiae; g) Gavilea littoralis; h) Gavilea lutea; i) Gavilea supralabellata.

Figura 1. Orquídeas de la Reserva de la Biosfera Torres del Paine: a) Chloraea chica; b) Chloraea leptopetala; c) Chloraea magellanica; d) Codonorchis lessonii; e) Gavilea araucana; f) Gavilea gladysiae; g) Gavilea littoralis; h) Gavilea lutea; i) Gavilea supralabellata. 
HABITAT AND COMMONNESS. This species is common. According with Domínguez (2004), this species is very rare and habits in wetlands locally termed as "Vegas" (Clausen et al. 2006). These habitats are dominated by species as Samolus spatulatus (Cav.) Duby (Domínguez 2004) and Euphrasia subexserta Benth., and located at small valleys containing wet and organic soils at the Patagonian steppe biotic province (sensu Pisano 1974). Although we found few populations at this habitat, the species becomes very common at shrublands dominated by Gaultheria mucronata (L.f.) Hook. et Arn. and Empetrum rubrum Vahl ex Willd. at the pre-Andean shrublands biotic province (sensu Pisano 1974).

Localities. Cerro Paine cattle ranch, Amarga Lake to Sarmiento Lake trekking trail, De Los Cisnes Lake, De los Flamencos Lake, Paso Feria, Pehoé-Italiano trekking trail. Phenology. January to February.

\section{Chloraea leptopetala M.N. Correa}

Terrestrial herb with stems $30-50 \mathrm{~cm}$, robust stems 30$50 \mathrm{~cm}$, erect. Basal leaves in a pseudo-rosette, oblonglanceolate, acute, sheathing at base and tapering to wide. Inflorescence in a dense raceme producing 20-35 bracteates flowers. Bracts 14-17 x 4-6 mm, linear to lanceolate, acute, green with dark-green veins. Flowers green-white. Upper outer perianth-segment 13-15 x 3-5 mm, oblong to oblong lanceolate, acute. Lateral outer perianth-segments linear, acute. Upper inner perianth-segments linear to lanceolate, acute. Labellum 12-15 x 3-5 mm, entire to obscurely 3lobed, obtuse, with undulate to involute margins, covered by white-yellow papillae. Column $8 \mathrm{~mm}$. Capsule ovoidoblong (Fig. 1 b).

Habitat and commonness. Populations of this species are very rare in woodlands dominated by Embothrium coccineum and Escallonia rubra at the pre-Andean shrubland biotic province (sensu Pisano 1974).

Localities. Cerro Paine range, Las Carretas trekking trail. Phenology. December.

\section{Chloraea magellanica Hook.f.}

Terrestrial herb with stems 15-60 cm, erect. Basal leaves $10-20 \times 2-5 \mathrm{~cm}$ in a pseudo-rosette, lanceolate, acute, sheathing at base and tapering to wide. Inflorescence in a lax raceme containing 3-6 bracteate flowers. Bract 25-35 x 7-10 mm, ovate, acute decreasing upwards, green with dark-green veins. Flowers white with green reticulate veins. Upper outer perianth-segment 25-35 x 5-10 mm, oblong to oblong-lanceolate, acute to subobtuse, sometimes cucculate at apex, white with green reticulate veins. Lateral outer perianth-segments lanceolate, acuminate at apex, fleshy, white at the basal half, greenish distally, reticulated by dark green veins. Upper inner perianth-segments 20-25 x 8-12 $\mathrm{mm}$ ovate to elliptic, acute, reticulate. Labellum $15-20 \times 8$ 10 , ovate, entire to obscurely 3-lobed, obtuse, covered by greenish capitate papillae, fleshy at apex. Column 12-16 $\mathrm{mm}$. Capsule cylindrical-ovoid (Fig $1 \mathrm{c}$ ). A population with albino-flowers and whitish-green leaves it was found near to Sarmiento Lake, in the Patagonian steppe dominated by Festuca gracillima Hook.f. and Mulinum spinosum (Cav.) Pers. Habitat. The individuals are not completely albinos, but a gradual lost in chlorophyll foliar content was observed (Fig. 2).

Habitat And Commonness. Populations of this species are common and widely distributed in the area, including the Patagonian steppe, pre-Andean shrublands, including those dominated by Gaultheria mucronata, Escallonia rubra (Ruiz et Pavon) Pers. (sensu Pisano 1974), and woodland communities dominated by Nothofagus antarctica (G.Forster) Oersted and forests dominated by Nothofagus pumilio (Poepp. et Endl.) Krasser (Vidal \& Reif 2011).

Localities. Cerro Paine cattle ranch, Cordón Masle, Paine Grande, Basin of Nordenkjoeld Lake, Salto Grande trekking trail, Paso Feria, Asencio Valley, Pehoé-Grey trekking trail. Phenology. January to March.

Codonorchis lessonii (Brongn.) Lindl.

Terrestrial herb with stems $5-50 \mathrm{~cm}$, decumbent to erect containing 1 or 2 cataphyll at the base of the stem. Leaves 20-25 x 20-25 mm, membranous, verticillate at the stem half, ovate, entire, sub-acute to obtuse, cuneate at base, sessile. Bract 8-10 x 2-5 mm, ovate, acute. Flowers solitary, terminal. Outher perianth-segments 8-20 x 6-8 mm, white, lanceolate, acute. Lateral inner perianth-segments 6-15 x 3-10 mm, ovatelanceolate, acute, white, containing purplish spots. Labellum 5-15 x 3-10, ovate to lanceolate, acute, white and covered by yellow capitate papillae, fleshy at apex. Collumn 10-13 cm. Capsule cylindrical-ellipsoid (Fig. 1 d).

Habitat and COMmonness. Populations of this species are common inside the forests dominated by $N$. pumilio in organic soils and closed canopy forests (Vidal \& Reif 2011), and also in the understory of forests dominated by $N$. betuloides (Domínguez 2004).

Localities. Cerro Paine, Cordón Masle forests, Pingo valley, Mount Ferrier.

Phenology. December to February.

\section{Gavilea araucana (Phil.) M.N.Correa}

Terrestrial herb with stems $50-70 \mathrm{~cm}$, erect. Basal leaves 13-25 x 2-4 cm in a pseudo-rosette, linear-lanceolate, acute and tapering to wide. Cauline leaves narrower sheatering the scape. Inflorescence in a lax raceme containing 15-20 bracteate flowers. Bract 13-15 x 3-5 mm, oval-lanceolate, acute. Upper outer perianth-segment 14-16 x 4-5 mm, ovallanceolate, acuminate, acute. Lateral outer perianth-segments 25-27 x 6-7 mm ovate-lanceolate, aristate, white-greenish with green veins. Upper inner perianth-segments $12-14 \mathrm{x}$ 
5-7 $\mathrm{mm}$, ovate to elliptic, papillose in veins in basal half. Labellum 8-10 x 9-11 mm, 3-lobed, as long as or slightly longer than wide, subcordate. Lateral lobes orbicular to elliptic. Median lobe 4-5 mm wide, triangular to trulliform with lacerate margins, aristate, covered by greenish papillae. Column 5-7 mm. Capsule ovoid-oblong (Fig. 1 e).

Habitat And COMmOnNess. This species is common. Although Domínguez (2004) mentions the presence of only 3 populations of this species in the entire area, we found frequently populations in forest gaps produced by landslides, which are a very common habitat at the mountain areas. In those areas low shrubland vegetation is dominated by Gaultheria mucronata and Empretrum rubrum, at the pre-Andean biotic province (sensu Pisano 1974). Some populations were also found in forest gaps at relatively high elevation (ca $700 \mathrm{~m}$ ) in Cerro Paine cattle ranch.
Localities: Asencio valley, Cerro Paine rangeland, Paso Feria.

Phenology: November to January.

\section{Gavilea gladysiae Chemisquy}

Terrestrial herb with stems 40-55 cm, erect. Leaves 14-21 x 2-3.5 cm in a pseudo rosette, oblong to linear-lanceolate, fleshy, apex acute, tapering to wide. Inflorescence in a dense raceme producing 10-17 flowers. Bracts 17-27 x 4$6 \mathrm{~mm}$, acuminate. Flowers greenish yellow. Upper outer perianth-segment 16-19 x 4-6 mm, oblong, acuminate, recurved, membranaceous, nerved. Lateral outer perianthsegments 10-14 x 3-5 mm, acuminate, membranaceous, nerved. Upper inner perianth-segments 9-12 x 35-55 mm, acuminate, nerved, with green excrescences over the veins, covering basal third of the segment. Labellum 8-13 x 5-7 $\mathrm{mm}$, apex cuspidate, margin repand, nerved. Column 6-7 mm. Capsule oblong-ovate (Fig. 1 f).

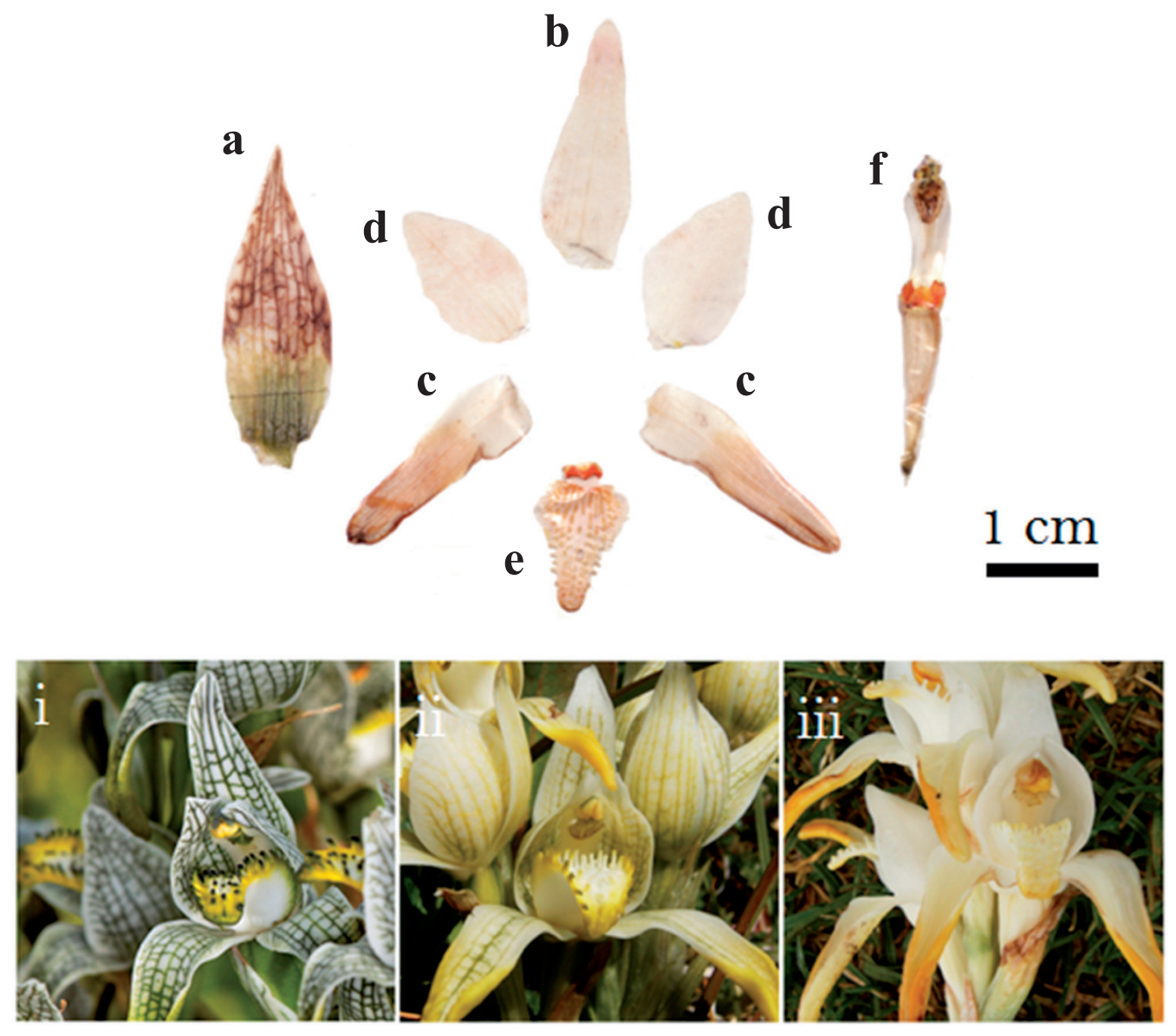

FIGURE 2. Disected perianth of the albino flower phenotype of Chloraea magellanica including: a) bract; b) upper outer perianth-segment; c) lateral outer perianth-segments; d) upper inner-perianth segments; e) labellum and; f) column. Pictures show the transitional phenotype of the species: i) normal phenotype; ii) Intermediate phenotype and iii) Phenotype with albino flowers.

Figura 2. Perianto disectado del fenotipo albino de Chloraea magellanica incluyendo: a) bráctea; b) segment superior del perianto externo; c) segmentos laterales del perianto externo; d) segmentos superiores del perianto interno; e) Labellum y; f) columna. Las fotografías muestran el fenotipo transicional de las especies: i) fenotipo normal; ii) fenotipo intermedio y iii) fenotipo con flores albinas. 
Habitat and COMmonness. This species is very rare. We found populations of this species in woodlands dominated by Embotrium coccineum and shrublands dominated by Gaultheria mucronata and Escallonia rubra at the preAndean biotic province (sensu Pisano 1974). According with Chemisquy (2009), this species growths also into forests formed by Nothofagus species, protected by the effect of wind. Although the habitat of this species is widely distributed into the study area, G. gladysiae seems to be a very rare species, founding only a few populations of this species.

LocAlities: near refugio "Paine Grande" and along Las Carretas trekking trail.

Phenology: December.

\section{Gavilea littoralis (Phil.) M.N.Correa}

Terrestrial herb with stems $30-50 \mathrm{~cm}$, erect. Leaves $10-20$ x 3-4 cm in a pseudo-rosette, oblong lanceolate, subobtuse, tapering to wide. Inflorescence in a dese raceme producing 10-18 flowers. Bracts 10-20 x 2-6 mm, lanceolate, acute. Flowers yellow with green veins. Upper outer perianthsegments 10-14 x 4-6 mm oblong to lanceolate acuminate, with green veins. Lateral outer perianth-segments 11-14 x 4-6 $\mathrm{mm}$, oblong to lanceolate, acuminate, with green veins. Upper inner perianth-segments 9-11 x 3-6 mm, oblong, obtuse, covered by green excrescences over the veins. Labellum 8-9 x 10-11 mm 3-lobbed. Lateral lobes oblong, obtuse, nerved, margin repand. Median lobe oblong, obtuse, sometimes retuse, covered by yellow-orange papillae. Column 5-6 mm. Capsule ovoid (Fig. 1 g).

Habitat and commonness. This species is rare. We found populations of this species in low-shrublands dominated by Gaultheria mucronata (Domínguez 2004, Vidal 2007) at the pre-Andean biotic province (sensu Pisano 1974).

Localities: Pingo valley, Paso Feria, Ferrier Mount, Grey trekking trail.

Phenology: December.

\section{Gavilea lutea (Pers.) M.N.Correa}

Terrestrial herb with stems $20-60 \mathrm{~cm}$, erect. Leaves 10-15 x $2-5 \mathrm{~cm}$ in a pseudo-rosette, ovate to oblong, subobtuse, tapering to wide. Inflorescence in a dense raceme producing 10-18 flowers. Bracts 15-30 x 4-11 mm, lanceolate, acuminate. Flowers yellow with green veins and papillae. Upper outer perianth-segments 11-14 x 3-6 mm oblong to lanceolate, acute to acuminate, with green veins. Lateral outer perianth-segments $14-16 \times 3-5 \mathrm{~mm}$, yellow, lanceolate, caudiculate, green and fleshy at apex. Upper inner perianthsegments 11-14 x 2-6 mm, ovate, obtuse. Labellum 4-7 x 3-4 mm, 3-lobbed. Lateral lobes oblong, obtuse, nerved, margin repand, without papillae. Median lobe oblong to triangular, obtuse, covered by yellow papillae. Column 3-5 mm. Capsule ovoid-oblong (Fig. $1 \mathrm{~h}$ ).
Habitat AND COMmONNESS. This species is common. We found populations of this species in low-shrublands dominated by Gaultheria mucronata (Domínguez 2004, Vidal 2007) at the pre-Andean biotic province (sensu Pisano 1974) and inside Nothofagus pumilio forests (Vidal \& Reif 2011) at the Deciduous Magellanic forest biotic province (sensu Pisano 1974).

Localities: Pingo valley, Paso Feria, Verde Lake, Ascencio Valley, French Valley.

Phenology: December to February.

\section{Gavilea supralabellata M.N. Correa}

Terrestrial herb with stems $20-30 \mathrm{~cm}$, erect. Leaves 5-8 x 1-2 cm, lanceolate, acute. Inflorescence in a dense raceme producing 10-15 flowers. Bracts 11-16 x 4-8 mm, lanceolate, acuminate. Flowers yellow with green veins and papillae. Upper outer perianth-segments $15-18 \times 3-5 \mathrm{~mm}$, lanceolate, acute, with green veins. Lateral outer perianth-segments 15-20 x 3-5 mm, yellow, lanceolate, caudiculate, green and fleshy at apex. Upper inner perianth-segments $12-14$ x 3-5 $\mathrm{mm}$, lanceolate, acute. Labellum 9-10 x 4-5 mm, entire or obscurely 3-lobbed, obtuse, fleshy at apex, densely covered by stitipate green papillae. Column 4-6 mm. Capsule ovoidoblong (Fig. 1 i).

Habitat And Commonness. This species is common. We found populations of this species in low-shrublands dominated by Gaultheria mucronata (Domínguez 2004, Vidal 2007) at the pre-Andean biotic province (sensu Pisano 1974) and inside Nothofagus pumilio forests (Vidal \& Reif 2011) at the Deciduous Magellanic forest biotic province (sensu Pisano 1974).

Localities: Pingo valley.

Phenology: December to February.

\section{DISCUSSION}

The richness of the orchids reported here adds one new species for the Torres del Paine Biosphere Reserve and the first aberrant albino-flowers individually found in situ for Chloraea magellanica. These findings put this area as one of the most diverse for this taxonomical group, as it contains about $35 \%$ of the orchids described for the Chilean Temperate-Austral floristic regions (sensu Bannister et al. 2012) and $75 \%$ of the orchids recorded in the Magallanes Region (Henríquez et al. 1995, Domínguez 2004, Novoa et al. 2006). The high proportion of orchids occurring in Torres del Paine Biosphere Reserve address two issues which would be able to implement here for conservation purposes: first, the need of develop species taxonomic inventories for biodiversity monitoring (Noss 1990, Cameron 2010) and the potential of ecotourism planning to increase biodiversity valuation. 
Taxonomic inventories for biodiversity monitoring. Because of the heterogeneity of the landscapes and habitats occurring along the environmental gradient in Torres del Paine Biosphere Reserve, a taxonomical inventory on orchid species would be useful for mapping the geographical range throughout metapopulations. Special research is necessary to select species as indicators for a determined kind of environmental performance (Noss 1990). For example, Codonorchis lessonii was found only inside the forests below the canopy, indicating its intolerance to high levels of light, or in other words, it is a good indicator for undisturbed old growth forests (Vidal et al. 2011). In a similar sense, some orchids are recognized to be highly sensitive with regard to plantpollination and plant mycorrhiza interactions (Lehnebach \& Riveros 2003). Thus they indicate the presence of other organisms (e.g. insects and fungi) and functional diversity (e.g. breeding systems) which are harder and more expensive to monitor. Plants are easy to record because of their restricted vagility and conspicuousness. A well-trained observer can therefore monitor the continuity of the populations initially recorded or add further recordings. Unfortunately, until now management plans in Torres del Paine have not included local information of plant population distributions. Even the plant or animal species lists are incomplete and outdated (CONAF 2007). Taxonomic inventories on orchid plant populations could be easily realized including information related to habitat structure, composition, topography, geographical location, human and natural disturbances and phenological stages. All this information can be helpful not only for establishing biodiversity indicators related to orchids distribution but also for predictive distribution mapping for places where they are harder to monitor (Noss 1990, Salem 2003, Remm \& Remm 2009), as well as the response of such populations to the deleterious effects of human disturbances or climatic change.

Ecotourism planning to increase biodiversity valuation. In TPBR an explosive increase of tourists has been experienced during the last 2 decades, as a consequence of the beauty of the landscapes and ecosystem representativeness. Concomitantly, a growing hotel infrastructure and services including trekking, ridings and nature tours give the change to explore the area. In 2010 about 150.000 tourists visited the area, but little information on plants and vegetation landscape is available for tourists interested on "botanizing" or exploring the vascular flora of the area (e.g. Guerrido \& Fernández 2007, Vidal 2007). This lack of knowledge not only makes it difficult to valuate the biodiversity, but also pauperize the tourist experience on a place having a not yet well explored potential. To implement touristic routs, to see orchids as flagship species would be a useful issue in order to increase the valuation of biodiversity. Flagship species are recognized as charismatic species in protected areas that, as popular symbols, increase the public conscience for biodiversity conservation (Walpole \& Leader-Williams 2002, Arango et al. 2007) and economic value (Cameron 2010).
Although plants are rare examples as flagship species, orchids seems to have all properties for that: they have an important ecological role in nature, they are ecological indicators, they are beautiful, they are sensible to influences by man and they are available during a great amount of time during the tourist season, because of its longer flowering periods. Planning touristic trails to see orchids and establishing them as flagship species, would be an initial idea to increase the valuation of biodiversity in Torres del Paine. Tourist guides can support important information for managers related to the location of new populations, phenological periods and habitat features because they travel continuously on remote areas of the park and can detect easily changes affecting populations. But a planning is needed, to instruct the guides to identify orchid species, as well as to avoid the tourist temptation to collect them as souvenirs. Tourist guides can acts as administrators of the park while they are guiding tourist groups.

Despite ecotourism always represent a potential threat for pristine areas, it would have an important role to play on biodiversity conservation. For example, the establishment of flagship species for conservation purposes has been perceived as an ecological sustainable initiative (Krüger 2005). It promotes public awareness for the protection of species, including raising funds for related taxonomic, ecological or restoration research. Reciprocally, tourism agencies would increase the quality of the product by training well-informed field guides, giving the tourist scientific-based information. Although the number of orchid species in Torres del Paine is certainly not impressive, their relatively narrow distributional range to the temperateaustral Chilean floristic regions, supports the idea that they are important for conservation issues including its promotion as flagship species. Torres del Paine contains now an unexplored potential for the conservation and valuation of its natural patrimony, but first basic information related to nature history and ecology of the species is needed, to select flagship species features and promote public conscience for species conservation: paraphrasing the environmentalist Baba Dioum, "we cannot protect what we do not know".

\section{ACKNOWLEDGMENTS}

This study was partially supported by the "Agrupación Medio Ambiental Torres del Paine" and "Fondo de Protección Ambiental" (Chilean Ministery of Environment). Thanks to the excursion guides of the "Hotel Las Torres" for the field help. CONAF gave the collect permissions. Thanks to Dr. Dr. h. c. Juergen Huss (Freiburg University) and Dr. Winfried Meier for suggestions to earlier version of the manuscript. The first author thanks the "Comisión Nacional de Ciencia y Tecnología de Chile" (CONICYT) and the "Deutscher Akademisher Austausch Dienst" (DAAD) for financing his Ph.D. studies at Freiburg University. 


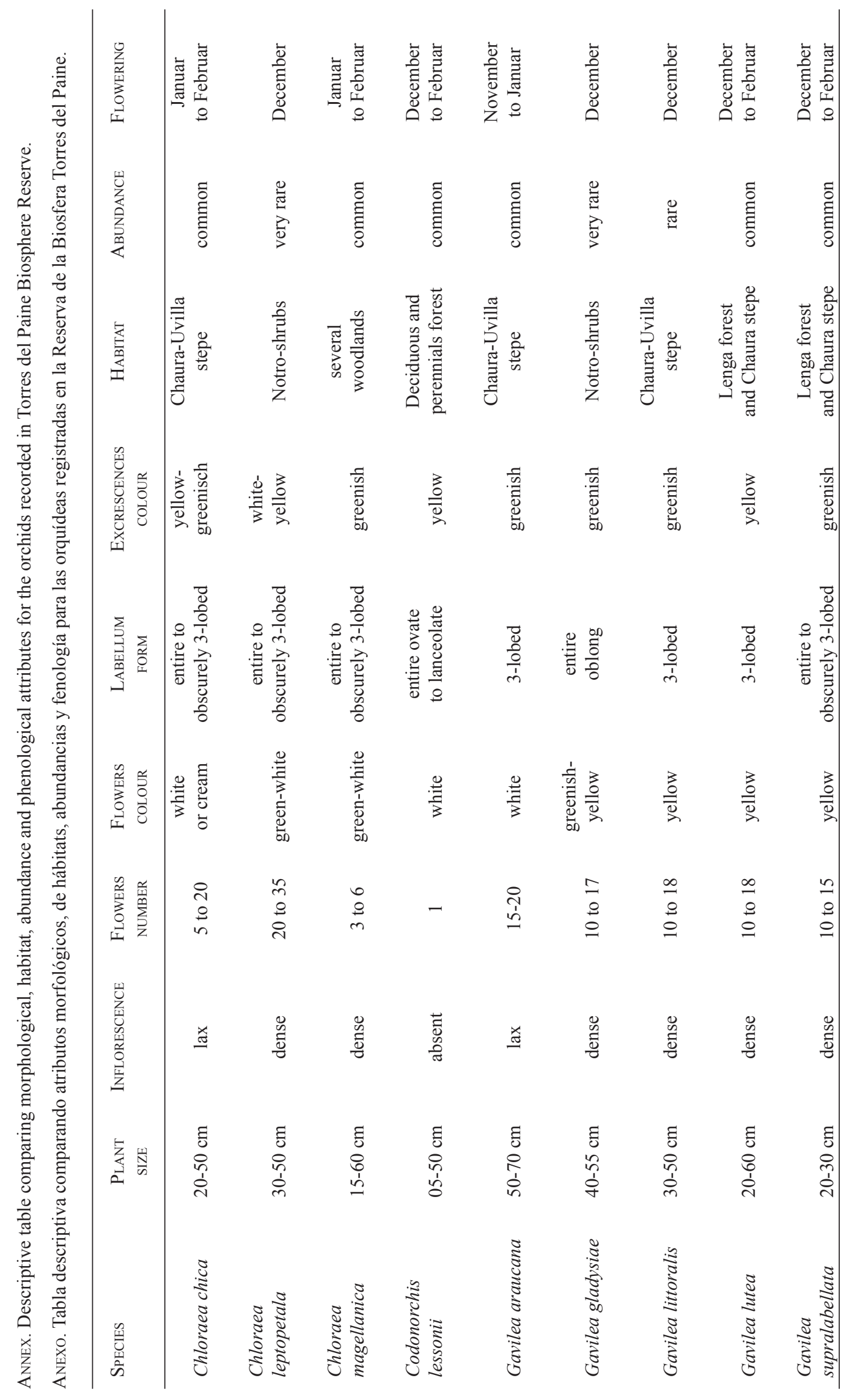




\section{REFERENCES}

Altenberger, U., R. Oberhansli, B. Putlitz \& K. Wemmer. 2003. Tectonic controls and Cenozoic magmatism at Torres del Paine, southern Andes (Chile, 51 degrees 10' S). Revista Geológica de Chile 30: 65-81.

Amigo, J. \& C. Ramírez. 1998. A bioclimatic classification of Chile: woodland communities in the temperate zone. Plant Ecology 136: 9-26.

Arango, X., R. Rozzi, F. Massardo, C.B. Anderson \& T. Ibarra. 2007. Descubrimiento e implementación del pájaro carpintero gigante (Camephilus magellanicus) como especie carismática: una aproximación biocultural para la conservación en la Reserva de la Biosfera Cabo de Hornos. Magallania 35: 71-88.

Armesto, J.J., I. Casassa \& O. Dollenz. 1992. Age structure and dynamics of Patagonian Beech forests in Torres del Paine National Park, Chile. Vegetatio 98: 13-22.

Arroyo, M.T.K., C.P. von Bohlen, L. Cavieres \& C. Marticorena. 1992. Survey of the alpine flora of Torres del Paine National Park. Gayana Botánica 49: 47-70.

Bannister, J.R., O.J. Vidal, E. Teneb \& V. Sandoval. 2012. Latitudinal patterns and regionalization of plant diversity along a $4,270 \mathrm{~km}$ gradient in continental Chile. Austral Ecology 37(4): 500-509.

CAmeron, K.M. 2010. On the value of taxonomy, phylogeny and systematics to orchid conservation: implications for China's Yachang orchid reserve. Botanical Review 76: 165-173.

Chemisquy, A. 2009. Gavilea gladysiae (Chloraeeae: Orchidaceae), a new orchid from southern Argentina and Chile. Brittonia 61: 201-205.

Clausen, J.C., I.M. Ortega, C.M. Glaude, R.A. Relyea, G. GARAY \& O. GuINEO. 2006. Classification of wetlands in a Patagonian national park, Chile. Wetlands 26: 217-229.

CONAF. 2007. Plan de manejo Parque Nacional Torres del Paine. $285 \mathrm{pp}$.

Correa, M.N. 1956. Las especies Argentinas del género Gavilea. Boletín de la Sociedad Argentina de Botánica 6: 73-86.

Couve, E. \& C. Vidal. 2007. Birds Torres del Paine field guide (second edition). Fantástico Sur, Punta Arenas, Chile. 270 pp.

Croft, J., N. Cross, S. Hinchcliffe, E. Nic Lughadha, P.F. Stevens, J.G. West \& G. Whitbread. 1999. Plant names for the $21^{\text {st }}$ century: the International Plant Names Index, a distributed data source of general accessibility. Taxon 48: 317-324.

Dollenz, O. \& J.S. Ivanovic. 1996. Secondary succession in a burned grassland in the National Park Torres del Paine, Magallanes, Chile. Anales del Instituto de la Patagonia 24: 15-28.

Domínguez, E. 2004. Catálogo preliminar de la familia Orchidaceae del Parque Nacional Torres del Paine, XII Región, Chile. Chloris Chilensis 7: www.chlorischile.cl

Domínguez, E. 2006. Chloraea leptopetala (Orchidaceae), una adición para la flora de la Región de Magallanes, Chile. Chloris Chilensis, 9: www.chlorischile.cl

Domínguez, E., A. Elvebakk, C. Marticorena \& A. Pauchard. 2006. Alien plants in Torres del Paine National Park, Chile. Gayana Botánica 63: 131-141.

Franklin, W.L., W.E. Johnson, R.J. Sarno \& J.A. Iriarte. 1999.
Ecology of the Patagonia puma Felis concolor patagonica in southern Chile. Biological Conservation 90: 33-40.

Garay, G., W.E. Johnson \& W.L. Franklin. 1991. Relative abundance of aquatic birds and their use of wetlands in the Patagonia of southern Chile. Revista Chilena de Historia Natural 64: 127-137.

Garay, G. \& O. Guineo. 2003. Fauna, flora y montaña de Torres del Paine. Amigos de la vida Silvestre, Punta Arenas, Chile. 310 pp.

Guerrido, C. \& D. Fernández. 2007. Flora Patagonia, southern forests. Fantástico Sur, Punta Arenas, Chile. 289 pp.

Henríquez, J.M., E. Pisano \& C. Marticorena. 1995. Catálogo de la flora vascular de Magallanes, Chile. Anales del Instituto de la Patagonia 23: 5-30.

JAKSIC, F.M., J.A. IRIARTE \& J.E. JimÉneZ. 2002. The raptors of Torres del Paine National Park, Chile: biodiversity and conservation. Revista Chilena de Historia Natural 75: 449-461.

Johnson, W.E. \& W.L. FrankLin. 1994. Role of the body size in the diets of sympatric gray and culpeo foxes. Journal of Mammalogy 75: 163-174.

KRÜGER, O. 2005. The role of ecotourism in conservation: panacea or Pandora's box? Biodiversity and Conservation 14: 579600.

Lehnebach, C.A. 2003. Preliminary checklist of the orchids of Chile. Botanical Journal of the Linnean Society 143: 449451.

Lehnebach, C.A. \& M. Riveros. 2003. Pollination biology of the Chilean endemic orchid Chloraea lamellata. Biodiversity and Conservation 12: 1741-1751.

Moore, D.M. 1983. Flora of Tierra del Fuego. Missouri Botanical Garden, USA. 395 pp.

Navarro-Cerrillo, R., A. Hayas, A. García-Ferrer, R. HernándezClemente, P. Dualde \& L. GonzÁlez. 2008. Caracterización de la situación posincendio en el área afectada por el incendio de 2005 en el Parque Nacional Torres del Paine (Chile), a partir de imágenes multiespectrales. Revista Chilena de Historia Natural 81: 95-110.

Noss, R.F. 1990. Indicators for monitoring biodiversity: a hierarchical approach. Conservation Biology 4: 355-364.

Novoa, P., J. Espejo, M. Cisternas, M. Rubio \& E. Domínguez. 2006. Guía de Campo de las Orquídeas Chilenas. Concepción, Corporación Chilena de la Madera, Chile. $120 \mathrm{pp}$.

Ortega, I.M. \& W.L. FrankLin. 1988. Feeding habitat utilization and preference by guanaco male groups in the Chilean Patagonia. Revista Chilena de Historia Natural 61: 209216.

Pauchard, A. \& P. Villarroel. 2002. Protected areas in Chile: history, current status and challenges. Natural Areas Journal 22: 318-330.

PilueK, C. \& P. Triboun. 2008. Wild orchids conservation for ecotourism in Thailand. Proceedings of the international workshop on ornamental plants 788: 69-76.

PisAno, E. 1974. Estudio ecológico de la región continental sur del área andino-patagónica. II. Contribución a la fitogeografía de la zona del parque nacional Torres del Paine. Anales del Instituto de la Patagonia 5: 59-104.

Remm, K. \& L. Remm. 2009. Similarity-based large scale distribution mapping of orchids. Biodiversity and Conservation 18: 
1629-1647.

Rivas-MartíneZ, S. 2005. Worldwide bioclimatic classification system. Phytosociological Research Center. Available in: http://www.globalbioclimatics.org/book/bioc/global_ bioclimatics 2.htm.

Roig, F.A., J. Anchorena, O. Dollenz, A.M. Faggi \& E. Méndez. 1985. Las comunidades vegetales de la Transecta Botánica de la Patagonia Austral. En: O. Boelcke, D.M. Moore \& F.A. Roig (eds.), Transecta Botánica de la Patagonia Austral. 350-518.

SALEM, B.B. 2003. Application of GIS to biodiversity monitoring. Journal of arid environments 54: 91-114.

Sarno, R.J., W.L. Franklin \& W.S. Prexl. 2000. Activity and population characteristics of Andean Condors in southern Chile. Revista Chilena de Historia Natural 73: 3-8.

VIDAL, O.J. 2005. Flora exótica adyacente a senderos remotos en el parque nacional Torres del Paine (Magallanes, Chile).
Tesis de Licenciatura en Ciencias Biológicas. Valdivia, Chile. Facultad de Ciencias, Universidad Austral de Chile. $135 \mathrm{p}$.

VidAL, O.J. 2007. Flora Torres del Paine field guide (second edition). Punta Arenas, Chile. Fantástico Sur. 348 pp.

VIDAL, O.J \& A. REIF. 2011. Effect of a tourist-ignited wildfire on Nothofagus pumilio forests at Torres del Paine biosphere reserve, Chile (Southern Patagonia). Bosque 32: 64-76.

Vidal, O.J, J.R. Bannister, V. Sandoval, Y. Pérez \& C. Ramírez. 2011. Woodland communities in the Chilean Cold Temperate Zone (Baker and Pascua Basins): floristic composition and morpho-ecological transition. Gayana Botánica 68: 141-154.

Walpole, M.J. \& N. Leader-Williams. 2002. Tourism and flagship in conservation. Biodiversity and Conservation 11: 543547.

Recibido: 27.09 .11

Aceptado: 28.02.12 